\title{
Health Risk Assessment of Heavy Metals in Soil of Dawu Water Source Area
}

\author{
Zhizheng LIU ${ }^{\mathrm{a}, \mathrm{b}}$, Henghua ZHU ${ }^{\mathrm{b}, \mathrm{c}, 1}$, Xiaomei SONG ${ }^{\mathrm{d}}$, Guoping Shi ${ }^{\mathrm{e}}$, \\ Binglin JIANG ${ }^{\mathrm{f}}$, Yuhan CHEN ${ }^{\mathrm{d}}$ and Shuang LI $^{\mathrm{b}}$ \\ anstitute of Marine Science and Technology, Shandong University, Qingdao, \\ Shandong, China \\ ${ }^{\mathrm{b}}$ Shandong Institutes of Geological Survey, Jinan, Shandong, China \\ ${ }^{\mathrm{c}}$ School of Environmental Studies, China University of Geosciences, Wuhan, China \\ ${ }^{\mathrm{d}}$ Shandong Geological Museum, Jinan, Shandong 250101, China \\ ' Shandong Provincial Institute of Land Surveying and Mapping, Jinan, Shandong \\ 250100, China \\ ${ }^{\mathrm{f}}$ Shandong Provincial Geo-mineral Engineering Exploration Institute, Jinan, \\ Shandong 250014, China
}

\begin{abstract}
Taking Zibo Dawu Water Source Area as the research area, with the help of MapGIS and SPSS analysis tools, the health risks Make an evaluation. The results showed that $\mathrm{As}, \mathrm{Pb}$, and $\mathrm{Ni}$ belonged to the risk-free level, $\mathrm{Hg}$ reached a high-risk level, and $\mathrm{Cd}$ reached a medium risk level. The source of $\mathrm{Cr}$ is similar to $\mathrm{Ni}, \mathrm{Cd}, \mathrm{Pb}, \mathrm{As}$, the source of $\mathrm{Ni}$ is similar to $\mathrm{Cd}, \mathrm{Pb}$, and the source of $\mathrm{Pb}$ is similar to $\mathrm{Hg}$. The comprehensive non-carcinogenic risk indexes of heavy metals for adults and children are 7.94E-03 and 3.38E-03, respectively, and there is no noncarcinogenic risk; the total carcinogenic risk indexes of heavy metals for adults and children are 5.52E-06 and 4.23E-06, respectively, There is a carcinogenic risk that the human body can bear, and the main influencing factors are Ni and Cr. Skin contact is the main way for heavy metals to cause health risks.
\end{abstract}

Keywords. Dawu water source area, soil heavy metals, health risk assessment

\section{Introduction}

As an important part of the earth's biosphere, Soil is an important part of terrestrial ecosystem [1]. If the soil environment is polluted and destroyed, its normal function will inevitably be affected [2-3].

Over the last few years, Industrialization and urbanization developed rapidly in China, industrial pollutants, fertilizers, pesticides, and domestic waste have entered the soil through various channels, which causes the increasingly serious problem of soil metal pollution in China [4-6]. The identification methods of typical pollutants include synthetical pollution evaluation method, potential hazard index method, health risk assessment, migration coefficient, positive definite matrix factor analysis, etc [7-9].

Many scholars at home and abroad have carried out research on soil pollution risk assessment, they analyzed farmland, irrigation area, mining area, vegetable base, city

\footnotetext{
${ }^{1}$ Henghua Zhu, Shandong Institutes of Geological Survey,Jinan, Shandong 250013, China; E-mail: hhzhu2008@sina.com.
} 
and other environment types in different regions, and finally made a series of research progress [10]. Francis Douay et al. [11] studied the content of heavy metals in the soil near the smelter and they found that the soil of urban and rural was contaminated by heavy mental elements such as $\mathrm{Cd}, \mathrm{Zn}$ and $\mathrm{Pb}$, and the health of residents living in the surrounding area was also at risk. $\mathrm{Hu} \mathrm{BF}$ et al. [12] conducted research in the Yangtze River Delta Coastal Industrial Zone to assess the health risk of heavy metals in soil. The results reported that children had lowest carcinogenic risk, and adults had the highest carcinogenic risk. The results showed that the cumulation of $\mathrm{Cd}$ was the heaviest, and it was in the medium risk level. Now the country attaches great importance to environmental protection, so it is very important to study the content and type of heavy metals in soil and make soil environmental quality assessment.

Linzi District, Zibo City, Shandong Province is an important industrial park. Industrial enterprises such as Qilu Petrochemical and Qiwangda Group are located here. These enterprises have made great contributions to national construction and economic development, but they still have an impact on the environment. The Dawu water source is located in Linzi District, which is an an important source of water for drinking and useing in Zibo City. The groundwater in Dawu water source has been polluted [13].

\section{Materials and Methods}

\subsection{Overview of the Research Area}

The Dawu water source is situated in Linzi area of Zibo City, which is the largest fractured karst landform in northern China. The source area is about $27 \mathrm{~km}^{2}$, and the annual average precipitation is $625.8 \mathrm{~mm}$. The atmospheric precipitation is the main recharge source of groundwater. The Dawu water source is a complete hydrogeological unit, with the Aihuaishu fault in the northeast, the Linzi River west of the fault in the southeast, the Jinling fault in the west, and Jinling town and Xinan town in the north [14]. The stratum distributed in the water source area is mainly Ordovician, Carboniferous-Permian and Quaternary stratum. The soil is mainly clay [13].

\subsection{Sampling and Sample Determination}

According to the urban and topographical distribution characteristics of the study area, the sampling points were arranged in accordance with the requirements of the "Technical Specifications for Soil Environmental Monitoring" (HJ/T 166-2004). thirtyeight sampling points were set up for this sampling (figure 1). Most sampling points only collected surface soils ranging from 0 to $0.2 \mathrm{~m}$, and the depth of collection in key monitoring areas could reach $3 \mathrm{~m}$. When collecting samples, use GPS to record the coordinates and fill in the soil sampling registration form. 


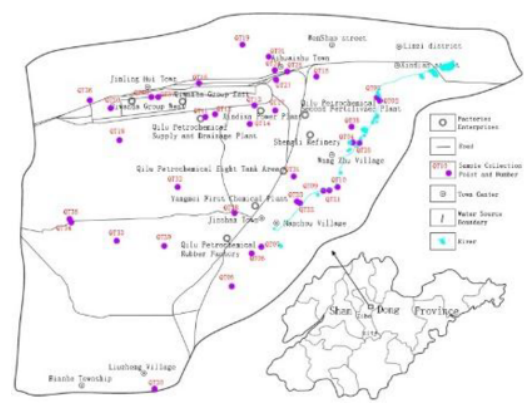

Figure 1. Distribution of soil samples.

The contents of $\mathrm{Cr}, \mathrm{Ni}, \mathrm{CD}, \mathrm{Pb}$, and $\mathrm{Hg}$ in the samples were analyzed in the laboratory. The amount of $\mathrm{Cd}$ and $\mathrm{Pb}$ in soil were determined by graphite furnace atomic absorption spectrometry, $\mathrm{Hg}$ and as by atomic fluorescence spectrometry, and $\mathrm{Cr}$ and $\mathrm{Ni}$ by flame atomic absorption spectrometry.

\subsection{Evaluation Method}

Health risk assessment method is used to evaluate human non-carcinogenic risk and human carcinogenic risk after chemical exposure [15-16]. In this paper, the mean value of heavy metal content in soil is calculated and evaluated. The calculation formulas as follow (1)-(3) for the average daily intake of adults and children through exposure. According to the guidelines of the U.S. Environmental Protection Agency and the manual of exposure factors, the health risk assessment is carried out, and the noncarcinogenic and carcinogenic risk index of heavy metals to human body calculated as follows (4)-(5).

$$
\begin{aligned}
& A D D_{\text {ing }}=\frac{C \times I n g R \times E F \times E D}{B W \times A T} \times 10^{-6} \\
& A D D_{\text {inh }}=\frac{C \times I n h R \times E F \times E D}{P E F \times B W \times A T} \times 10^{-6} \\
& A D D_{\text {derm }}=\frac{C \times S A \times S L \times A B S \times E F \times E D}{B W \times A T} \times 10^{-6} \\
& H I=\sum_{i=1}^{n} H Q_{i}=\sum_{i=1}^{n} \frac{A D D_{i}}{R f D_{i}} \\
& T C R=\sum_{i=1}^{n} C R_{i}=\sum_{i=1}^{n}\left(A D D_{i} \times S F_{i}\right)
\end{aligned}
$$

Where: $A D D_{\text {ing }}$ represents the average daily intake of oral; $A D D_{\text {inh }}$ represents the average daily intake through respiration; $A D D_{\text {derm }}$ represents the average daily intake through skin contact, $\mathrm{mg} \cdot(\mathrm{kg} \cdot \mathrm{d})^{-1} ; C$ represents the amount of various heavy metals in the soil; $H I$ represents the comprehensive non-carcinogenic health risk index of the region, $H Q$ represents the non-carcinogenic health risk of a certain heavy metal element; $T C R$ and $C R$ are comprehensive and single-element carcinogenic health risk indexes, respectively. The parameters and meanings used are shown in table 1 and table 2 [17-19]. 
According to the "Guidelines for Risk Assessment of Contaminated Sites" promulgated by the Ministry of Environmental Protection of China, if $\mathrm{HI}<1$, the pollutants will not pose a health hazard to the surrounding environment or people, if $\mathrm{HI} \geq 1$; the pollutants will cause health risk to the surrounding environment. The carcinogenic risk was divided into no risk $\left(\mathrm{TCR}<10^{-6}\right)$, tolerable $\operatorname{risk}\left(10^{-6} \leq \mathrm{TCR}<10^{-4}\right)$ and intolerable risk $\left(\mathrm{TCR} \geq 10^{-4}\right)$.

Table 1. Evaluation parameters of exposure model.

\begin{tabular}{|c|c|c|c|c|}
\hline Parameter & Meaning & Adult & Child & Unit \\
\hline IngR & Soil uptake rate & 100 & 200 & $\mathrm{mg} \cdot \mathrm{d}^{-1}$ \\
\hline InhR & Respiratory rate & 16 & 7.6 & $\mathrm{~m}^{3} \cdot \mathrm{d}^{-1}$ \\
\hline EF & Exposure frequency & 350 & 350 & $d \cdot a^{-1}$ \\
\hline ED & Exposure years & 24 & 6 & $\mathrm{a}$ \\
\hline BW & Average weight & 60.5 & 27.7 & $\mathrm{~kg}$ \\
\hline AT & $\begin{array}{l}\text { Average exposure time (non- } \\
\text { carcinogenic) }\end{array}$ & $\mathrm{ED} \times 365$ & $\mathrm{ED} \times 365$ & $\mathrm{~d}$ \\
\hline AT & $\begin{array}{l}\text { Average exposure time } \\
\text { (carcinogenic) }\end{array}$ & $75.8 \times 365$ & $75.8 \times 365$ & $\mathrm{~d}$ \\
\hline PEF & Particulate matter release factor & $1.36 \times 10^{9}$ & $1.36 \times 10^{9}$ & $\mathrm{~m}^{3} \cdot \mathrm{kg}^{-1}$ \\
\hline SA & Skin exposure area & 5700 & 2800 & $\mathrm{~cm}^{2}$ \\
\hline SL & Skin adhesion coefficient & 0.07 & 0.2 & $\mathrm{mg} \cdot(\mathrm{cm} \cdot \mathrm{d})^{-1}$ \\
\hline ABS & Skin absorption factor & 0.001 & 0.001 & - \\
\hline
\end{tabular}

Table 2. Health risk assessment exposure parameters.

\begin{tabular}{lllllll}
\hline \multirow{2}{*}{ Element } & \multicolumn{2}{l}{ Reference (RfD) } & \multicolumn{3}{l}{ Slope coefficient (SF) } \\
\cline { 2 - 6 } & $\begin{array}{l}\text { Breathing } \\
\text { inhalation }\end{array}$ & $\begin{array}{l}\text { Skin } \\
\text { contact }\end{array}$ & Oral intake & $\begin{array}{l}\text { Breathing } \\
\text { inhalation }\end{array}$ & Skin contact & Oral intake \\
\hline $\mathbf{C r}$ & $2.86 \times 10^{-5}$ & $6 \times 10^{-5}$ & $3 \times 10^{-3}$ & $4.2 \times 10^{1}$ & $2 \times 10^{1}$ & $5 \times 10^{-1}$ \\
\hline $\mathbf{N i}$ & $9 \times 10^{-5}$ & $5.4 \times 10^{-3}$ & $2 \times 10^{-2}$ & $8.4 \times 10^{-1}$ & $4.25 \times 10^{1}$ & $1.7 \times 10^{0}$ \\
\hline $\mathbf{C d}$ & $1 \times 10^{-5}$ & $1 \times 10^{-5}$ & $1 \times 10^{-3}$ & $6.3 \times 10^{0}$ & $6.3 \times 10^{0}$ & $6.1 \times 10^{0}$ \\
\hline $\mathbf{P b}$ & $3.52 \times 10^{-3}$ & $5.25 \times 10^{-4}$ & $3.5 \times 10^{-3}$ & - & - & $8.5 \times 10^{-3}$ \\
\hline $\mathbf{A s}$ & $3 \times 10^{-4}$ & $1.23 \times 10^{-4}$ & $3 \times 10^{-4}$ & $1.51 \times 10^{1}$ & $3.66 \times 10^{0}$ & $1.5 \times 10^{0}$ \\
\hline $\mathbf{H g}$ & $8.57 \times 10^{-5}$ & $2.1 \times 10^{-5}$ & $3 \times 10^{-4}$ & - & - & - \\
\hline
\end{tabular}

\section{Results and Analysis}

The results calculated using formulas (1)-(5) are shown in table 3 and table 4 . The consequences of the non-carcinogenic risk evaluation showed that the total noncarcinogenic risk HI value of various ways was comprehensively compared, and the order of the impact of each heavy metal on adults through the three ways was $\mathrm{Cr}>$ $\mathrm{As}>\mathrm{Pb}>\mathrm{Cd}>\mathrm{Hg}>\mathrm{Ni}$; the order of impact on children was $\mathrm{As}>\mathrm{Pb}>\mathrm{Cd}>\mathrm{Hg}>\mathrm{Ni}>\mathrm{Cr}$, the non-carcinogenic risk index values of various metals were all less than 1, indicating that these six kinds of heavy metals would not cause non-carcinogenic risks to adults and children. Among the three different ways of HI of the same heavy metal, skin contact was the main way to cause non-carcinogenesis. The greatest impact on adults was $\mathrm{Cr}$, which could cause lesions in human organs, and the greatest impact on children was As. When considering multiple elements, the total non-carcinogenic risk 
index of the study area was less than 1, meaning that people in the area were not exposed to non-carcinogenic risk.

Table 3. Non-carcinogenic risk index for adults and children.

\begin{tabular}{lllllllll}
\hline \multicolumn{1}{l}{ Adult } & \multicolumn{7}{c}{ Children } \\
\hline & Inhalation & $\begin{array}{l}\text { Skin } \\
\text { contact }\end{array}$ & Oral ingestion & HI & Inhalation & $\begin{array}{l}\text { Skin } \\
\text { contact }\end{array}$ & Oral ingestion & HI \\
\hline $\mathbf{C r}$ & $4.23 \mathrm{E}-10$ & $6.84 \mathrm{E}-03$ & $2.52 \mathrm{E}-11$ & $6.84 \mathrm{E}-03$ & $4.39 \mathrm{E}-10$ & $2.99 \mathrm{E}-08$ & $1.10 \mathrm{E}-10$ & $3.05 \mathrm{E}-08$ \\
\hline $\mathbf{N i}$ & $6.91 \mathrm{E}-11$ & $3.91 \mathrm{E}-05$ & $1.94 \mathrm{E}-12$ & $3.91 \mathrm{E}-05$ & $7.17 \mathrm{E}-11$ & $1.20 \mathrm{E}-04$ & $8.49 \mathrm{E}-12$ & $1.20 \mathrm{E}-04$ \\
\hline $\mathbf{C d}$ & $3.36 \mathrm{E}-12$ & $1.14 \mathrm{E}-04$ & $2.10 \mathrm{E}-13$ & $1.14 \mathrm{E}-04$ & $3.48 \mathrm{E}-12$ & $3.49 \mathrm{E}-04$ & $9.16 \mathrm{E}-13$ & $3.49 \mathrm{E}-04$ \\
\hline $\mathbf{P b}$ & $1.64 \mathrm{E}-12$ & $3.72 \mathrm{E}-04$ & $1.03 \mathrm{E}-11$ & $3.72 \mathrm{E}-04$ & $1.70 \mathrm{E}-12$ & $1.14 \mathrm{E}-03$ & $4.49 \mathrm{E}-11$ & $1.14 \mathrm{E}-03$ \\
\hline $\mathbf{A s}$ & $6.51 \mathrm{E}-12$ & $5.39 \mathrm{E}-04$ & $4.07 \mathrm{E}-11$ & $5.39 \mathrm{E}-04$ & $6.76 \mathrm{E}-12$ & $1.65 \mathrm{E}-03$ & $1.78 \mathrm{E}-10$ & $1.65 \mathrm{E}-03$ \\
\hline $\mathbf{H g}$ & $2.83 \mathrm{E}-13$ & $3.91 \mathrm{E}-05$ & $5.05 \mathrm{E}-13$ & $3.91 \mathrm{E}-05$ & $2.93 \mathrm{E}-13$ & $1.20 \mathrm{E}-04$ & $2.21 \mathrm{E}-12$ & $1.20 \mathrm{E}-04$ \\
\hline Total & & & & $7.94 \mathrm{E}-03$ & & & & $3.38 \mathrm{E}-03$ \\
\hline
\end{tabular}

The carcinogenic risk assessment results showed that when only a single heavy metal was considered, the magnitude of the carcinogenic risk impact on adults and children was $\mathrm{Ni}>\mathrm{Cr}>\mathrm{As}>\mathrm{Cd}>\mathrm{Pb}$, and skin contact was the main route of carcinogenic. According to the requirements of "Guidelines for risk assessment of contaminated sites", $\mathrm{Cr}$ and $\mathrm{Ni}$ were the main influencing elements and had a certain risk of carcinogenesis. $\mathrm{Cr}$ and $\mathrm{Ni}$ might cause harm to the human body through skin contact, but within the range of the human body. The study area had no carcinogenic risk that the human body cannot bear.

Table 4. Cancer risk index for adults and children.

\begin{tabular}{lllllllll}
\hline \multicolumn{2}{ll}{ Adult } & \multicolumn{7}{c}{ Children } \\
\hline & Inhalation & $\begin{array}{l}\text { Skin } \\
\text { contact }\end{array}$ & $\begin{array}{l}\text { Oral } \\
\text { ingestion }\end{array}$ & TCR & Inhalation & $\begin{array}{l}\text { Skin } \\
\text { contact }\end{array}$ & $\begin{array}{l}\text { Oral } \\
\text { ingestion }\end{array}$ & TCR \\
\hline $\mathbf{C r}$ & $1.61 \mathrm{E}-13$ & $2.60 \mathrm{E}-06$ & $1.20 \mathrm{E}-14$ & $2.60 \mathrm{E}-06$ & $4.17 \mathrm{E}-14$ & $1.99 \mathrm{E}-06$ & $1.31 \mathrm{E}-14$ & $1.99 \mathrm{E}-06$ \\
\hline $\mathbf{N i}$ & $1.65 \mathrm{E}-15$ & $2.84 \mathrm{E}-06$ & $2.09 \mathrm{E}-14$ & $2.84 \mathrm{E}-06$ & $4.29 \mathrm{E}-16$ & $2.18 \mathrm{E}-06$ & $2.29 \mathrm{E}-14$ & $2.18 \mathrm{E}-06$ \\
\hline $\mathbf{C d}$ & $6.70 \mathrm{E}-17$ & $2.27 \mathrm{E}-09$ & $4.05 \mathrm{E}-16$ & $2.27 \mathrm{E}-09$ & $1.74 \mathrm{E}-17$ & $1.74 \mathrm{E}-09$ & $4.42 \mathrm{E}-16$ & $1.74 \mathrm{E}-09$ \\
\hline $\mathbf{P b}$ & - & - & $9.69 \mathrm{E}-17$ & $9.69 \mathrm{E}-17$ & - & - & $1.06 \mathrm{E}-16$ & $1.06 \mathrm{E}-16$ \\
\hline $\mathbf{A s}$ & $9.34 \mathrm{E}-15$ & $7.68 \mathrm{E}-08$ & $5.80 \mathrm{E}-15$ & $7.68 \mathrm{E}-08$ & $2.42 \mathrm{E}-15$ & $5.89 \mathrm{E}-08$ & $6.33 \mathrm{E}-15$ & $5.89 \mathrm{E}-08$ \\
\hline $\mathbf{H g}$ & - & - & - & - & - & - & - & - \\
\hline Total & & & & & $5.52 \mathrm{E}-06$ & & & $4.23 \mathrm{E}-06$ \\
\hline
\end{tabular}

\section{Conclusion}

The health risk evaluation results showed that both adults and children had a noncarcinogenic risk index of less than 1, meaning that the non-carcinogenic risk of heavy metals to the human body was small. $\mathrm{Cr}$ and $\mathrm{Ni}$ have certain carcinogenic risks, but they would not have unbearable effects on the human body. Skin contact was the main 
influence path of heavy metals, which was related to the occurrence characteristics of soil heavy metals in human living environment.

\section{Acknowledgement}

This paper has been supported by Construction of 3D visualization information system of Dawu Water Source Area in Zibo City(SDLR - 2017-138).

\section{References}

[1] Dong HM, Zhao JB, Song YG, Liu HF. Characteristics and risk assessment of heavy metal content in soils of Apple Orchard with different cultivating years in Baishui county on the Loess Plateau. Research of Soil and Water Conservation. 2021 Jul; 28(05): 205-211.

[2] Li CF, Cao JF, Lv JS, Yao L, Wu QY. Ecological risk assessment of soil heavy metals for different types of land use and evaluation of human health. Environmental Science. 2018 Dec; 39(12): 56285638.

[3] Han P, Wang JH, Feng XY, Ma ZH, Lu AX, Wei L, Yan LB. Ecological risk assessment of heavy metals in soil in Shunyi, Beijing. Journal of Agro-Environment Science. 2015 Jan; 34(01): 103-109.

[4] Meng YS, Gao LL, Li ZJ, Li D, Zhu HK, Ma YH. Research on risk assessment models and methods of heavy metal pollution in farmland soil. Earth and Environment. 2020 May; 48(04): 489-495.

[5] Dai B, Lv JS, Zhan JC, Zhang ZL, Liu Y, Zhou RJ. Assessment of Sources, spatial distribution and ecological risk of heavy metals in soils in a typical industry-based city of Shandong Province, Eastern China. Environmental Science. 2015 Feb; 36(02): 507-515.

[6] Zhang H, Wang H, Tang HY, Wen JW, Xu RK. Heavy metal pollution characteristics and health risk evaluation of soil and vegetables in various functional areas of lead-zinc tailings pond. Acta Scientiae Circumstantiate. 2020 Mar; 40(03): 1085-1094.

[7] Ji C, Hou DW, Li FZ, Bao GJ, Deng AP, Shen HJ, Sun H. Assessment and spatial characteristics analysis of human health risk of heavy metals in cultivated soil. Environmental Science. 2020 Mar; 41(03): 1440-1448.

[8] Ye M, Zhang JR, Zhang LL, Li ZH, Li XY, Zhou YZ. Transfer factor and health risk assessment of heavy metals in a soil-crop system in a high incidence area of nasopharyngeal carcinoma, Guangdong. Environmental Science. 2020 Dec; 41(12): 5579-5588.

[9] Wu ZY, Zhang LN, Xia TX, Jia XY, Li HY, Wang SJ. Quantitative assessment of human health risks based on soil heavy metals and PAHS source: Take a polluted industrial site of Beijing as an example. Environmental Science. 2020 Apr; 41(09): 4180-4196.

[10] Guo XD, Zhao YS, He HY, Sun QF. Assessment of heavy metal pollution and potential ecological risks of Hunchun Basin, Jilin Province, China. Bulletin of Science and Technology. 2019 Feb; 35(02): 225-230

[11] Francis D, Aurélie P, Julie P, Hervé F, Antoine R, Hélène R, Bertrand G. Assessment of potential health risk for inhabitants living near a former lead smelter. Part 1: metal concentrations in soils, agricultural crops, and homegrown vegetables. Environmental Monitoring and Assessment. 2013 May; 185(5): 3665-3680.

[12] Hu BF, Wang JY, Jin B, Li Y, Shi Z. Assessment of the potential health risks of heavy metals in soils in a coastal industrial region of the Yangtze River Delta. Environmental Science and Pollution Research international. 2017 Aug; 24(24): 19816-19826.

[13] Wang WJ, Wu TL, Zhou DM, Chen HM. Advances in soil heavy metal pollution evaluation based on biliometrics analysis. Journal of Agro-Environment Science. 2017 Dec; 36(12): 2365-2378.

[14] Gao ZJ, Sun JF, Lu TM, Wang XY, Yang LZ, Liu ZZ. Types and assessment of organic pollutants in groundwater of Dawu source area in Zibo. Journal of Shandong University of Science and Technology (Natural Science). 2019 Jul; 38(04): 1-9.

[15] Lin CQ, Cai YH, Hu TR, Yu RL, Hao CL, Huang HB. Bioaccessibility and health risks of the heavy metals in soil-rice system of Southwest Fujian Province. Environmental Science. 2020 Jul; 42(01): 359367.

[16] Yao CB, Zhou MZ, Xiong KN, Zhang D, Gu BQ, Yang H, Zhang XR. Health risk assessment of chromium and cobalt in soils and crops around the Ni-Mo polymetallic mining area. Journal of Anhui Agricultural University. 2020 Mar; 47(01): 109-117. 
[17] Chen YX, Jiang XS, Wang Y, Zhuang DF. Assessment of ecological environment and human health of heavy metals in mining area based on GIS. Acta Scientiae Circumstantiae. 2017 Sep; 38(04): 16421652.

[18] Fan JN, He XM, Du W, Xiong J, Song GQ, Zhang MJ, Yang J. Analysis and comparing environmental baseline values of heavy metals in soil based on standardized method and statistical method. Journal of Huazhong Agricultural University. 2020 Dec; 40(01): 160-167.

[19] Liu F, Guan YM, Che GB, Yang CW. Environmental monitoring and ecological risk assessment of heavy metals in soils of typical industrial areas in Siping City. Shandong Chemical Industry. 2019 Dec; 48(23): 236-238. 